\title{
Call Center Agents and Expatriate Writers: \\ Twin Subjects of New Indian Capital[1]
}

\section{Ragini Tharoor Srinivasan}

Siddhartha Deb's award-winning work of reportage, The Beautiful and the Damned: A Portrait of the New India, begins in an Indian call center. In January 2004, Deb, who had been pursuing a Ph.D. in New York, returned to India, where he was born and raised, on assignment from the Guardian. His task was to secure a job as a call center agent and write an insider account of working at the center—or, what some were calling the backroom—of the global economy. Fulfilling this charge required fabricating an alter-ego for his CV and masking the signs of his American education. "In order to become globalized through the call centre," Deb would later write, "I had to stop being globalized and become a provincial Indian" (8). An accomplished writer of Anglophone journalism who had recently published his first novel, Deb also had to learn a new language. He enrolled in a "call center English" training course in Delhi, "paying more for that brief course of a few weeks than I had for my entire state-subsidized higher education in India" (9).

Like many New India narratives, which relate India's neo-Hegelian return to worldhistorical significance in the "Asian Century," Deb's story inverts dominant understandings of the provincial and the global. Expecting that his American bonafides have prepared him to participate in India's new “enterprise culture" (Gooptu), Deb instead finds that his life experience in the West is insufficient, even disqualifying, when his goal is participation in the outsourcing industry. The provincial Indian call center-aspirant is the one whose ambitions are legibly global, not the diaspora-returned cosmopolitan writer. Furthermore, the call center is not in the business of transforming Indian voices into American approximates, as is conventionally 
assumed. Rather, it is in the business of producing Indian English as itself distinctly and audibly global. As Deb's chronicle continues, he meets other New Indians, including entrepreneurial farmers and Indian Institute of Technology (IIT) entrance-exam test-prep consultants, but he returns often to the call center and what it represents: "a generation of Indian youth who were being empowered by capitalism, people who had begun to break down the old restrictions of caste, class and gender, and who now exemplified the new India" (8).

This essay considers both why and how contemporary textual mediations of the New India, like Deb's, produced the call center agent as the iconic subject of India's insertion into global capitalism. Why did the call center agent emerge as the paradigmatic New Indian, and not the entrepreneurial farmer, test-prep consultant, reality television star, Bollywood-aspirant, IT worker, or any other participant in the New Indian project of "self-maximization...self-making, self-help...self-development [and] self-advancement" (Gooptu 8-9)? Call centers did not emerge in India; they had their earliest incarnation in the "phone rooms" of American retailers and airlines in the mid-1970s (Fisher 13). At the time of writing, India is also not the exclusive or even the primary site for the establishment of outsourcing operations by Western multi- and transnational corporations; both Mexico and the Philippines have overtaken India in that regard. How, then, did the call center come to dominate (and it dominates still) popular imaginings of India's role in the global economy? How did its mediations of voice and language in particular inflect the critical apprehension of the New India?

The call center achieved metonymic relation to the New India through its simultaneous treatment in a range of literary and critical texts, genres, and disciplines that jointly produced the discourse on India's global emergence. By the middle of the first decade of the $21^{\text {st }}$ century, the New India moniker had gained currency among pundits, politicians, journalists, and academics 
as a descriptor of India's economic “dream run” between 2003 and 2008, the nation's capitalist ambitions, and the confluence of its "hard" economic and "soft" cultural power (D'Costa). The discourse on New India suffused the economic, cultural, and political spheres equally, undergirding evaluations of India's changing professional norms, youth culture, and political platforms like the Bharatiya Janata Party's (BJP) “India Shining” campaign in 2004. New India was a temporal signifier of India after the liberalization of its financial markets, starting with the International Monetary Fund (IMF)-led economic reforms in 1991, and a qualitative descriptor of a rising, enterprising global India in the post-American world.

New India was also a nationalist pledge that a newly self-reliant and confident India would no longer require its diasporic populations in the United States and the United Kingdom as loci of mediation. Responding to the pontifications of Non-Resident Indian talking head, Pankaj Mishra, India-based pundit R. Jagannathan cheered "the rise of new, more independent voices that [could talk] authoritatively about a changing India" without relying on self-appointed ambassadors like Mishra in the West. "What is the point of writers who call themselves Indian authors, but who have no Indian readers?" pulp fictionist Chetan Bhagat criticized internationally-celebrated expatriates like Salman Rushdie. "I want my country to read me" (Ramesh). If postcoloniality was "the condition of . . a comprador intelligentsia: of a relatively small, Western-style, Western-trained, group of writers and thinkers who mediate the trade in cultural commodities of world capitalism at the periphery" (Appiah 149), then the rise of a global New India was meant to mark the abatement of such mediation. That many of New India's celebrated cultural artifacts and authoritative voices in the early, post-millennial years were, in fact, routed through the West (Slumdog Millionaire, directed by Danny Boyle and produced in the United Kingdom, is just one prominent example) did little to temper the exuberant self- 
congratulation, which saw its apex in the Hindu nationalist BJP's electoral triumph in 2014 and concurrent appointment of the India-educated, Rashtriya Swayamsevak Sangh-member and former Gujarat Chief Minister, Narendra Modi, as India's fifteenth Prime Minister. In September 2014, when Modi addressed the United Nations in Hindi, many cheered the fact that India was finally being represented on its own terms: "Last century, [Jawaharlal] Nehru and [M.K.] Gandhi spoke in English to enlighten the world about India ... Modi speaks in Hindi to do just the same" (Agrawal).

Given these widely shared investments in the idea of India speaking in its own voice, it is striking that the call center - an institution best known for the practice of accent modificationwould become the primary spatial, social, and economic sign of India's emergent globality. In the late 1990s, the call center was the functional "backroom" of the global economy, the dirty secret of major Western multi- and transnational corporations like Citibank, AT\&T, AOL, and Goldman Sachs. In 2000, Arundhati Roy cited a Call Centre College in Gurgaon as exemplary evidence of "how easily an ancient civilization can be made to abase itself completely." In her view, the "new" capitalist formations represented by the call center revealed continuities with colonialism. Observing the agent's conformance to Western corporate imperatives and somatic alignment to foreign time zones, many critics agreed that call center agents were continuing the project of British colonial subjectivation in the time of American neoliberal capital. They were “cyber-coolies” (Nadeem 2009), speaking subjects who had ironically come to stand-in for the masses once known as Gayatri Chakravorty Spivak’s “silent” subaltern. To make matters worse, the call center confirmed global imaginings of Indian servility.[2]

At the same time, nationalist celebrants noted with excitement that India was now "one of the main nodes of globalization" (Deb 7). Why bring up old colonial baggage, they countered 
arguments like Roy's, if the call center meant India's increasing relevance to the world economy? Some argued that the call center was a dynamic space of potential for a generation of would-be global citizens. After all, an entire aspiring middle-class in rural India was supported by remittances from call center work, which had "its own sources of enchantment" (Mankekar, 2011, 228). Meanwhile, as optimistic Indian pundits eyed the call center as a sign of India's increasing clout, the Western media stoked anxieties about globalization. "Outsourcing" and "offshoring" came up often as rhetorical scapegoats for American decline in the 2004 and 2008 U.S. elections. The call center agent was seen both as a shadow of a "real" American and as a threat who indexed the Western subject's increasing reliance on Eastern technological management. Documentaries like 1-800-INDIA: Importing a White-Collar Economy (2005) assuaged American fears of Indian takeover by interspersing scenes of offices with slums; poverty was offered as a palliative to the viewer who needed to be reassured that India was still safely behind the times (Rowe et al., 2011, 203).

By the second decade of the $21^{\text {st }}$ century, it was evident that India's bursts of outsized economic growth in the preceding decade had not translated into development for the majority of Indians. Some proposed that New India was "an artefact of the imagination," a fantasy of an entrepreneurial India expunging the "autarchic post-colonial development state" (Gooptu 3, 1). New India may have had dozens of billionaires, but there were still hundreds of millions in poverty. The death toll of suiciding farmers in the state of Maharashtra alone amounted to an average of ten per day, and a single corporation, the Tatas, ran over a hundred companies in eighty countries (Roy 2014, 9). While "rising China" seemed to refer to the statistical inevitability of China's economic ascendance, with the U.S. debt holdings to prove it, "New India" was notable precisely for its repeated failures to transcend its status as an ideological 
smokescreen for domestic policy failure. Viewed against the 2008 Beijing Olympics and the Expo 2010 Shanghai China, the 2010 Commonwealth Games in New Delhi were a highly visible example of India's abortive ascendance.

Was the call center's promise also a sham, or was it a dynamic space of potential for aspiring global subjects? Did it represent the perfect marriage of tradition and opportunity? In the first two decades of the $21^{\text {st }}$ century, numerous expatriate writers returned to India from diaspora in order to pursue questions such as these (Srinivasan 2015, 2017). At stake was the question of the "newness" of New India itself: did it mark a decisive transition from the postcolonial to the global? Journalists like Deb, Anand Giridharadas, and Somini Sengupta, novelists like Chetan Bhagat and Bharati Mukherjee, and scholars from across the disciplines sought out India-based subjects from a range of class positions whose professional and personal itineraries could help them understand and write about the nation's ambivalent transformations. In the resulting accounts, the call center agent is consistently presented as the New Indian exemplar: an enterprising individual whose "virtual migrations"[3] both decenter and shore up the West, whose transactional English gives voice to a hitherto unheard Indian Anglophonism, and whose participation in the outsourcing industry confirms New India's centrality to the new international division of labor.

Today, over half a dozen monograph-length ethnographies of the Indian call center have been published (Aneesh 2015, Basi, Mirchandani, Nadeem 2011, Patel, Rowe et al. 2013). In addition, the Indian call center and its agents have been discussed in recent work by Rey Chow, Akhil Gupta, Shannon Jackson, Purnima Mankekar, Meredith McGuire, Jisha Menon, Sarah Sharma, Raka Shome, Selma Sonntag, and Kalindi Vora, among others. To put a finer point on it, the call center is such a powerful trope of Indian globality that it has merited scholarly 
treatment in the fields of Anthropology, Communication, Cultural Studies, Film Studies, Geography, Linguistics, Literature, New Media, Performance Studies, Politics, Rhetoric, and Sociology — to say nothing of its depictions in the works of theater practitioners, filmmakers, and artists around the world.[4] Treatments and emphases vary: Vora reads the call center agent in relation to the gestational surrogate, as one who provides "life support" by investing "vital energy" in other, comparatively more valuable bodies (2015). Gupta and Mankekar read call center labor in relation to recent Marxist theorizations of immaterial labor, affect, and alienation (2016). For Menon, the call center presents an opportunity to re-theorize "cosmopolitanism from below" (2013).

Plainly, the call center's appeal to writers and scholars of New India is multipronged. The emblematic scene of global interconnection, it literalizes what David Harvey famously called “time-space compression” (1989): I sit in Tucson, Arizona, and call my bank, and am connected to tech-support across the world. An infamous scene of accent modification, the call center seems to continue the process of "[recruiting the colonized] into the ideological state apparatus that was English" (Chow 2014, 8-10). At once oriented toward the West and rooted in the East and global South, the call center also affords the closest thing to "a direct experience of the centrelessness of capitalism" (Fisher 6). It therefore promises to shed light on the simultaneously universal and particular nature of Indian capitalism.

From this perspective, the call center provides a new vantage from which to enter a longstanding conversation within postcolonial studies about the putative differences of Indian capitalism and globality from their Western counterparts. One version of this line of inquiry goes like this: When capital arrives at the colonial periphery, does it encounter the colonial as something to be appropriated and homogenized, or does it experience colonial difference as a 
limit to its expansion? Is there a genuine form of difference in the periphery that escapes capital? Are there subaltern and indigenous histories and life-worlds that are not part of capitalism's "life-process" (Chakrabarty 64)? In recent years, the primary assumption undergirding these questions - namely, that capital must either subsume or retreat from difference, as opposed to function alongside it—has been revised, notably in Kalyan Sanyal's Rethinking Capitalist Development, which is one of the texts that occasions the essays collected here. Sanyal argues that critics of contemporary globalization, like Roy and Chow quoted above, mistakenly read phenomena like outsourcing as part of a return to "the imperialist face of capital ... trying to subjugate the third world to its absolute dominance" (189-190). Following his line of argument, such assessments, and perhaps even expectations, of "return" motivate misreadings of sites like the call center as an example of "old exploitation dressed up in a new costume" (Deb 7), as opposed to a "radically new ... [modality] of power" (Sanyal 190).

Does the call center in fact represent a new modality of power? Are the lives and lifeworlds of call center agents appropriated and homogenized by the imperatives of capital, or do they make legible and audible a form of postcolonial difference from a global norm? In my research on the interdisciplinary literature on the call center, I do actually detect a series of returns, but not, to be clear, the form of repetition rejected by Sanyal. As a scholar of literature and literary discourse, I offer an account of postcolonial capitalism's returns that focuses on the language of capitalism, English: how it is read, written, and heard; and how India's global legibility continues to be staked on its subjects' differential performances of the Anglophonic. I am interested in the putative difference between Indian postcoloniality and Indian globality, and I propose that a postcolonial literary discourse animated by tensions around diasporic location and the English language's purchase on Indian realities might help us to understand the 
transnational interconnection, racialization, body shopping, and outsourcing we associate with globalization. How are global capitalist institutions and their subjects recognized as global in the first place? I argue that the call center agent became the paradigmatic New Indian subject because of her continuity with, as opposed to her disruption of, earlier forms of Indian global subjectivity. Specifically, the forms of economic and social (im)mobility presented by the call center agent, as well as her linguistic and vocal performances of India, are formally symmetrical to those of the expatriate writer in diaspora, the "global" figure who dominated Indian Anglophone literature and criticism in its "postcolonial" phase, prior to its transfiguration into the world Anglophone literary rubric.

Until the emergence of New India, the expatriate writer was the most visible bearer of India's cultural capital. The iconic, Booker-of-Booker-winning novelist Salman Rushdie comes first to mind; in the 1980s and 1990s, he was indisputably India's most celebrated literary figure, the great allegorist of Partition who, with Midnight's Children and The Satanic Verses, made a hybridized, chutneyfied, "mixed-up" Indian English a veritable form of "cosmopolitan style" (Walkowitz 2006). Rushdie was in the company of numerous other writers who together disseminated Indian soft power, secured India's legibility on the world (literary) stage, and variously primed the reception of the global New India with their narratives of the nation's postcolonial itineraries. Figure 1, published in the June 23/30, 1997, issue of the New Yorker with the caption "India's leading novelists," depicts just such a group of celebrated expatriate writers - including Amit Chaudhuri, Anita Desai, Amitav Ghosh, Rohinton Mistry, and of course Rushdie himself - smiling for a photographer whose gaze stands in for the adulation of Englishlanguage readers around the world.[5]

We can compare this image to one of the call center agents who I am arguing are the 
symbolic heirs of these writers: the virtual migrants to their migrants; the embodiment of the future to their pursuit of the past; the speakers of a global "call center English" to their high literary Englishes (Figure 2). On the surface, Figures 1 and 2 seem to offer a relation of opposition: the cheery, sated, identifiable faces of Rushdie and co., versus the faceless and nameless Indian call center agents, sitting in rows in geometrically-partitioned office space, addressing an English-speaking population that is aggrieved, not admiring. But relations of opposition are just that, relations, and the call center agent's and expatriate writer's disparate subject positions in fact indicate the broader contours and sweep of the global.[6] Both expatriate writers and call center agents are ideologically constructed Indian subjects whose voices travel throughout the world in technologically mediated forms, whether books or phone calls. Both are Indian subjects who speak "for" India and "from" India, and in so doing are effectively India's ambassadors outside the territorial bounds of the nation-state. Both collectivities have been hailed by the West: by elite media apparatuses and publishing companies, and by the multi- and transnational corporations behind the phenomenon of Business-Process Outsourcing. Both, by responding to that hailing, condition their and India's present and future intelligibility.

When I first began to give talks on this research, I received some pushback on the twinning of figures who exist on different sides of the international division of labor. Expatriate writers are elite, urban cosmopolitans-Indian participants in a global literary culture whose itineraries reflect what Aihwa Ong famously termed their "flexible citizenship" (1999). Call center agents are lower-middle class subjects who may be upwardly mobile in class terms, but whose international migratory itineraries are purely virtual—subjects who only ever leave India telephonically, if, that is, we can understand them to be leaving India at all. They are, in Simon Gikandi's words, "those who are not yet quite cosmopolitan even when they inhabit the spaces 
that have come to be inscribed as global" (23). How, then, could I equate call center labor, with its vexed affective and immaterial aspects, with the privileged activity and worldly circulation of expatriate writing? Did the comparison between jet-setting cosmopolitans like Rushdie and constrained provincials like the call center agent not risk obscuring significant class and caste differences?

Such questions are in fact at the heart of this inquiry. By juxtaposing figures with disparate access to vehicles of transnational mobility, circulation, and employment, I seek to resist the assumption that the only relation possible between those occupying different class positions is one of ignorance, exploitation, or ventriloquism. It is both despite and because of their structural differences of position that Siddhartha Deb returned to India to impersonate an aspiring call center agent; both despite and because of such differences that scholars of Indian subcontinental origin returned to India from their academic-institutional locations in the West to do fieldwork in the call center. Such "return-writers," as I have termed them elsewhere, were drawn to the call center agents because of their familiarity as much as their distinctiveness, because of the critical resemblance between virtual migration and immigration, and because they, too, despite their relative privilege, are subject to dominant ideologies undergirding the social, cultural, and economic complex of global Anglophonism.

Expatriate writers are figures who chose, in the classic postcolonial narrative, to emigrate away from India; they then "return[ed] to India in what they [wrote] . . discovering . . . the place that they [had] left behind" (Kumar xiv). The call center agent's virtual (imaginative) migrations away from India mirror, in an inverse way, these virtual (literary) returns. The expatriate writer departed from an India that could not accommodate its aspirational literary class and did not, in any case, have a critical mass of English-language readers to receive its works. The call center 
agent remains in an India that nevertheless relies on multi- and transnational corporations to utilize the economic potential of its young, ambitious human resources. Expatriate writers and call center agents speak to and from India from spatially incongruous locations, but as their words travel, questions about what is or is not distinctively Indian about their respective voices begin to trump differences of class or geographical position. For despite the fact that call center agents are located in India, they, with their "Americanized" identities, accents, acquired knowledges, habits and tastes, do not have any more purchase on "Indianness" than the diasporabased, expatriate writers once did (Rowe et al., 2013, 144). The "authenticity" of both sets of definitionally hybrid subjects is in question — a reminder that the adjudication of authenticity has as much to do with the politics of locution as that of location.

To return to the question of juxtaposition across class lines, vexed questions of locution and location are as pertinent to the reception of works by scholars like Homi Bhabha, Dipesh Chakrabarty, and Gayatri Chakravorty Spivak as they are to that of lauded fictionists and journalists, on the one hand, and to call center agents, on the other. These and other expatriate scholars of Indian subcontinental origin gained prominence as the vanguard of postcolonial studies in the 1980s and 1990s, securing India's centrality to that now-international discourse in the process (Srinivasan 2018). They are key subjects of India's postcolonial (cultural) capital, if not of Indian postcolonial capitalism as such. Moreover, the critical textual productions of expatriate scholars are as saturated with expectations of native informancy and ethnographic accuracy as are the writings of their literary counterparts. Both scholars and literary writers legible as "native" continue to be hailed by the Anglo-American academy in order to diversify fields, departments, and curricula, just as the call center agent is an ideologically constructed "third world" subject who seems to promise direct access to the New India. 
I am suggesting that we read together figures like Rushdie, the call center agent, and even Spivak in order to posit and begin to understand the relationship between a high critical locution like, "Here are subsistence farmers, unorganized peasant labor, the tribals ... To confront them is not to represent (vertreten) them but to learn to represent (darstellen) ourselves" (Spivak 259), and New Indian banker-turned-novelist Amish Tripathi's claim that, "people frankly don't care for ... stories of the British Raj or the struggles of NRIs ... India is rich again, and people want to hear stories about themselves-about our call centre generation" (Joshi 311-312). The first is part of a critique of how "Western intellectual production" has been "complicit with Western international economic interests" (Spivak 237); the second is an affirmation of Indian cultural production that represents India's complicity with Western international economic interests. One is an attempt to chart a space for a post-postrepresentationalist vocabulary; the other takes no pains to hide its essentialist agenda. How might we approach the shared terrain of these projects-Spivak's critical intervention regarding the re-presentation of the subaltern and Tripathi's exuberant claim that the New India finally desires its own stories-without giving in to operative conceptual oppositions between high and low discourse, diaspora and nation, cosmopolitan and local, worldly and provincial? Such oppositions also motor our understandings of the postcolonial and the global, making it harder to see, I propose, the ways in which the postcolonial was always already a form of insertion into the global capitalist order, and how the global economy continues to profit off the forms of difference (here, Indian difference) consolidated in the name of the postcolonial.

I want to turn now to two examples of stories about Indians "themselves," as Tripathi puts it, in order to further plumb the tenuous postcolonial-global and nation-diaspora binaries undergirding the juxtaposition of this essay's titular figures. In the early 2000s, Bharati 
Mukherjee, a pioneering writer of the Asian/American immigrant experience, had a telephonic encounter with an Indian call center agent. She described this experience to an interviewer some years later:

As we got talking, she seemed to take me into her confidence and said yes, I'm speaking to you from Bangalore. And I was touched by this confession, or should I call it revelation, and at the same time intrigued by the phenomenon of a whole group of Bangalore-based employees assuming American identities during their work shift to earn their livelihood, then presumably reverting to their customary languages and personalities during their off-the-job hours. (Lavigilante 179-180)

Mukherjee experienced a moment of identification ("I was touched") with a woman she recognized as a fellow Indian, a fellow woman, and, most significantly, a fellow inhabitant of an "American" identity, if only for the space-time of a work shift.[7] Inspired by the virtual encounter, she undertook a series of research trips to Bangalore, where she interviewed call center agents for what would become the 2011 novel, Miss New India.

The call center agent presented Mukherjee with the opportunity to reterritorialize and indigenize what were previously textual and imaginative attachments to an Indianness that had become, in her own words, "a metaphor, a particular way of comprehending the world" (1985, 3). In response to that infamous claim, Delhi-based literary critic Meenakhi Mukherjee (no relation to Bharati) offered this: "The problem is that for those who live at home, who are not global migrants, the reality of India has to be daily confronted at a non-metaphoric level" (1993, 2610). Meenakshi Mukherjee's response to Bharati lays bare longstanding anxieties within postcolonial studies about the over-valuation of diasporic experience and the equation within diaspora studies of nationness with extra-territoriality.[8] Her privileging of the space of home, the temporality of the daily, and the proximity of reality is also characteristic of those critics who read the expatriate writer's migratory itineraries as opportunistic and, relatedly, decry the international prominence of Indian Anglophone literature relative to Indian vernacular 
literatures. Anglophonism in all cases only exacerbates the problem of diasporic location, as writing in English is understood to be a form of movement away from "the reality of India"; it is a linguistic operation of metaphoric transfer that, like emigration, amounts to a mode of departure.

This is the context in which pundits cheer Narendra Modi's Hindi speeches and literary scholars tout the emergence of New Indian literatures that, in contradistinction to the Indian Anglophone literatures of old, "talk directly of, and to New India" (Varughese 152). The critical anointment of "paperback king" Chetan Bhagat as the literary face of New India—“a representative voice of the new middle class" (Anjaria and Shapiro Anjaria 200)—is a case in point. Bhagat, who moved back to India from Hong Kong in the early 2000s, has written seven bestselling novels, two nonfiction collections, and newspapers columns in both English and Hindi, all with the self-professed purpose of reaching "the majority, the real India" (Bhagat 2014, xix). This is an aim he returns to often in his public presentations and within the narrative universes of his fictions. For example, One Night@ the CallCenter (ON@CC) is prefaced with an autobiographical frame story describing call center agents as the youth population most clearly faced with "the real challenges" of "modern India" (Bhagat 2005, 6).

Call center novels like Mukherjee's Miss New India and Bhagat's ON@CC purport to do what Varughese describes as "direct" talking and Bhagat describes as addressing "the real India" by updating the idea of English's cosmopolitan imaginary with evidence of its newfangled provincial one. Miss New India tells the story of aspiring call center agent Anjali Bose, who moves from small-town Bihar to big-city Bangalore. There, she is inducted into the world of "customer-support service specialists" (Mukherjee 2011, 135) who brandish their call center English as "a sign of competence" (165). Anjali is fascinated by the way they speak: "Landlords 
are crooks"; "She's a real cutie. Hot and going fast"; "Dudes, dudes, what is this, a bitch session?"; "They got 'tudes...but we got game" (88-91). Bhagat's approximation of the English taught and utilized in the outsourcing industry is similar. In ON@CC, sentences are short, dialogue is stripped down, and there is little narrative description. A call center agent whose lipstick is "as thick as cocoa" is voted "hottest chick at Connections" (Bhagat 2005, 23); an irritating mother "should be put in jail and made to watch daytime TV all day" (174). "Pass me the next dumb customer," one agent says (181); “[R]eality sucks," adds another (182).

In fact, the English spoken in call centers is a far richer object than either Mukherjee's or Bhagat's novels would suggest. When Siddhartha Deb eventually gets a job at a call center in Noida, the call center English he hears is "an idiosyncratic [rendition] of [a] Northern Irish accent...brought back [by the call center trainers] from the BT facility in Belfast" (10). In sociologist A. Aneesh's telling, call center English is a highly technical linguistic form that the outsourcing industry is attempting to produce as a form of placeless, global accent. In Neutral Accent, Aneesh reproduces notes from a call center training class that show just how fraught the decision of how to pronounce a word like "laboratory" can be. The American pronunciation stresses the first syllable, while dropping the first "o"; the British pronunciation stresses the second syllable, while dropping the second "o." A neutral, global, Indian pronunciation (and I will return to that seemingly contradictory constellation of terms) keeps both "o's" while maintaining the same stress on each syllable (Aneesh 2015, 61-62). To some extent, Bhagat is aware of these nuances. At one point in $O N @ C C$, his protagonist discusses the difficulty of pronouncing the letter " $T$ " in an American accent: " $T$ can be silent, so 'internet' becomes 'innernet' ... T and $\mathrm{N}$ merge ... [when] $\mathrm{T}$ falls in the middle ... 'water" is 'wauder.' The last category, if you still care, is when Americans say T like a T" (45). The passage is savvy, and yet 
it stands out because it is the only one in the novel that attends with any nuance to the language in which it is meant to speak.

The conventional argument about the language of novels like ON@CC is that since they are not addressed to Western audiences (Bhagat has been voluble on this point), they do not have to dress up their English in stylized, ethnic markers. Thus, the call center novel doesn't utilize Sanskrit words like "karma," "dharma," and "shanti," which Vikram Chandra once used as story titles, only to later be accused of trying to "signal Indianness in the West" (Chandra 2000). They also don't include any of Rushdie's inventive, syncretic language play, as in the passage in Midnight's Children where he discusses "the fortunate ambiguity of transliteration": how the Urdu word "buddha," meaning old man, is spelled just like "Buddha" (402). But I would argue that the call center novel's linguistic dressing down evinces a similar "anxiety of Indianness" to that which Meenakshi Mukherjee identified in 1993 as endemic to Indian Anglophone literary writing. If writers then were subject to the twin pressures of "easy international accessibility" and "the global marketplace" (Mukherjee 1993, 2610), then the New Indian writer's mode of voicing the "real" New India reflects the pressures of a global marketplace that mistakes accessibility on a linguistic level for genuine purchase on the nation. The fact that Miss New India, which was written by an Asian/American, also falls into this trap suggests that the assumption of internal address covers for something else: the ready association of the demotic with the massifying, quantitative operations of the global, and the attendant dismissal of the postcolonial (as) highbrow.

If this is the voice of the call center novel, in whose voice does the call center agent actually speak? Is the Indian customer service agent an imperfect copy of an American or British ideal? Kiran Mirchandani's Phone Clones and Shehzad Nadeem's Dead Ringers, both 
ethnographies, give these questions titular pride of place, in language that clearly returns to the postcolonial discourse on mimicry that assumed critical currency through the work of Homi Bhabha. For Mirchandani, Bhabha's account of mimicry speaks to "an effective strategy of colonial power" that finds its contemporary analogue in the managerial mechanisms of the call center and larger BPO industries (158n33). Mimicry, she writes, both authenticates the call center's administrative power over workers' lives and admits the possibility of their selfdetermination. Nadeem quotes Bhabha's famous refrain ("almost the same, but not quite") while also attributing his account of mimicry to Walter Benjamin's assessment of the human “compulsion...to become and behave like something else." In the call center, Nadeem writes, this universal compulsion is "choreographed," regulated, subject to "rational control and the rules of capital accumulation" (2011, 41-42).

On the one hand, it is not hard to see why Bhabha's account of mimicry would have appeal for scholars of the call center. Mimicry is a strategy of power and knowledge that relies on, as opposed to simply producing as an unconscious effect, a subversion of identity and difference. It is not just a colonial imposition, but also an available tactic of the colonized. Bhabha follows Jacques Lacan's definition of mimicry's effect as that of "becoming mottled" (one does not mimic so as to become the other, but one mimics and becomes a mottled version of both self and other), while pursuing Frantz Fanon's provocative argument that the only possible destiny for the black man is "white." The ultimate threat to colonial authority is the simultaneity of mimicry's rearticulation and disavowal of this destiny.

Between the resemblance of "almost the same" and the menace of "not quite," the call center agent has the ability to rupture the international division of labor in the time of globalization - and not only by appearing as a threat to the security of American jobs. Rowe, et 
al. stress that agents "resist" being cultivated as neoliberal subjects through "little and big ways of maintaining Indianness: taking time back, engaging in fleeting refusals" $(2013,72)$.

Mirchandani and Nadeem chart the ways that Indian call center agents attempt to maximize their performance scores while subverting certain routine procedures and expectations of customer service work. Rather than becoming an "irrevocably subaltern" subject, the call center agent understood as Bhabha's mimic assumes the "elements of a resilient_-indeed, mobile...selfhood" (Chow 2002, 105).

On the other hand, these same studies invite a reading of call center impersonation as what Rey Chow has called, in her work on ethnicity, "coercive mimeticism": the imperative of appearing as oneself, of performing one's ethnic, racialized, gendered, or in this case Indian difference from a putatively unmarked norm, a norm which is then shored up by the performance of difference in question. Chow specifically distinguishes coercive mimeticism (which she terms mimeticism-type 3) from Bhabha's "resistance" model of mimicry (which she terms mimeticism-type 2), which dominates cultural theory while continuing to emphasize "whiteness as the ultimate superior value" (Chow, 2002, 106). Coercive mimeticism, by contrast, is a process in which the figure or quantity to be mimicked is a stereotyped ideal of the ethnic (or non-white) subject herself. In this light, call center mimicry can be read as a process whereby the agent must strive, not to approximate whiteness or Americanness as the superior value, but rather a form of global Indianness, analogizable to ethnicity in Chow's terms. Indeed, in the "familiar imagings" (Chow 2002, 107) of globalization, the ideal customer service agent is actually an Indian subject, a brown subject, and a speaker of Indian English.

And yet, Bhabha's account of mimicry so dominates the cultural theoretical imaginary of post- and neo-colonial relations that even Chow, in her recent work on languaging, lapses into a 
reading of call center mimicry as mimeticism-type 2 . She writes that the call center agent's aural approximations lay bare the operations of linguistic "skin tones"; under the conditions of global telephonic interconnection, the voice becomes the skin, "on which is now inscribed an explicit demand, left over from an unequal historical relation" $(2014,9)$. The authors of Answer the Call similarly argue that call center "agents are trained to speak like Americans...in processes of virtual assimilation in which they learn to inhabit whiteness" (68). Again, this equation of Americanness with whiteness, and of mimicry as a process of "approximating" that whiteness, misses the significance of the call center agent's necessary approximation and inhabitance of an ethnicized global Indianness. It does not take into consideration, in other words, the presence of Indian ethnic subjects in diaspora, like Bharati Mukherjee, who are as likely to answer the call and hear their Indian English as any white American, or otherwise dominant, global subject.

How Indian English became global English is a story Aneesh tells in Neutral Accent, and he begins with a tale we've heard before. In late 2005, the Wisconsin-based scholar attempted to get a job as a voice and accent trainer at the Datys call center in Gurgaon. Having lived and worked in the United States for over a decade, he was confident of his experiential credentials. And yet, like Siddhartha Deb with whose return to India this essay begins, Aneesh swiftly found that he was actually too Western for the job. The call center manager, Payal, asked him to stop using an American accent and "start using a neutral accent, instead." She offered her own spoken English as a model. When Aneesh protested that Payal's "Indian English" was not exactly "plain and neutral," she demurred: "Indian English is global English. It is neither American nor British" $(2015,3)$.

Aneesh goes on to define the kind of neutrality that Payal advocates as a form of "indifference to difference," in the sense that "the global techno-economy has ... managed to 
remain neutral to the day/night difference" $(2015,112)$. Here and in related passages, he uses neutrality in two senses of the word. First, neutrality is equated with economic "indifference": a lack of care for the somatic requirements of the call center agent, who is expected to transform her sleeping, eating, and other practices of living in order to labor during the night. Second, neutrality speaks to the neoliberal rationality of economic opportunism and expediency that characterizes the integrated global economy. What matters is the efficacy of global communication, not its particulars. What counts is the number of profitable transactions, not when or where or even between whom they occur.

And yet, when, where, and whom do matter, as the call center agents' location in India is the underlying condition of their desirability to the outsourcing industry. Aneesh's characterization of the language of capital as "indifferent to difference" captures the callous affect of the integrated economy, but downplays the global marketability of difference, even differences that have supposedly been "neutralized." Here is anthropologist Mathangi Krishnamurthy's description of "effective communication" in the call center: "Words were mispronounced but confidently. Grammar was garbled but without pauses. Agents spoke assertively, their sentences fluid. Language disabilities had metamorphosed into smart communication" (88). Krishnamurthy's account reveals not only the tenacity of Indian English's difference from American, British, or otherwise Transatlantic registers, but also suggests the utility of that tenacity. To speak call center English is to speak a dominant, global language, the language of capital, in a way that is at once non-threatening in its patent irregularities and highly efficient as a conduit for international exchange. To speak call center English is to speak Indian English neutrally, for the purpose of monetizable communication, but it is foremost a way of speaking Indian English. 
Call center accent neutralization is thus both about eliminating difference (the difference of "Mother Tongue Influence," for example) and about cultivating specific forms of difference, which is why both Deb and Aneesh have to learn a new language in order to work in the call center. To return to Bhabha, "to be Anglicized" or Americanized "is emphatically not to be English" or American—but it is to be Indian (128). The call center agent is trained to speak in a voice that sounds "global" and "everyday"—which is to say, I wish to stress again, Indian —as opposed to American, British, or Transatlantic (Aneesh 2015, 68). Even for Mirchandani, the point is never simply that the Indian call center agent become a "clone" of an American worker, but rather that call center agents "refashion themselves into ideal Indian workers" (1, my emphasis). Mirchandani terms this refashioning "authenticity work": the Indian agent must become the best version of herself by "emulating, through voice, an ideal transnational call center worker" (3). As Aneesh writes, "cultural simulation [becomes] the basis of authentic performance" $(2006,93)$.

How does the call center agent's task of making Indian English global relate to the expatriate writer's task of making English Indian? As discussed above, it is frequently taken for granted that outsourcing work involves a kind of violent identitarian and linguistic interpellation, in which an Indian Keerthi becomes Karen and Shyam becomes Sam, even though India's call centers "[dropped] the fake accents" as early as 2003, emphasizing instead the production of "neutral accents" that could be "universally understandable" (Merchant 13). By contrast, the literary productions of expatriate writers - and I understand literature as itself an identitarian and linguistic performance - are assumed to be volitional: the writer chooses to write in a globally legible English, to participate in the complex of diasporic Anglophonism, to produce "born translated" books that are always already worldly and world literature (Walkowitz 2015). The 
Indian English spoken by call center agents in India is supposed to sound as if it issues from nowhere. The English written by expatriate writers in diaspora is supposed to be intelligible everywhere, and yet maintain a distinctly Indian flavor or style. These tasks and expectations are different sides of the same coin. Both call center agents and expatriate writers are charged with communicating in a global language neutrally, in a way that nevertheless renders them susceptible to the charge of mimicry. Both the neutral accented English of the call center agent and the cosmopolitan stylings of Anglophone expatriate writers involve specific mediations of difference from a global linguistic norm.

As linguist Vineeta Chand's research demonstrates, “ALL Indians,” even expatriate writers and scholars, must negotiate the "national-level, globally imposed assessments" of fluency, accent, and general linguistic competency to which the call center agent is daily subject (414). Such assessments of English vernacularity and nativity are operative, for example, in many well-known works of literary scholarship. The section on "The Postcolonial Novel" in Pascale Casanova's The World Republic of Letters is exemplary in this regard. In Casanova's account, European languages are "exported" to "outlying lands," where, "[f]or a language no less than for the literary tradition associated with it, [outsiders] supply a new way of keeping up with modernity" (120). By that same token, she stresses, what seem like "peripheral literary innovations" by these outsiders are often "typically English and largely outmoded [literary techniques]" (120). While Casanova's broader critique is aimed at those British literary critics and prize-giving bodies who she claims are exercising neo-imperial authority in claiming postcolonial literatures for the Commonwealth, undergirding her critique is the idea that writers like Rushdie are outsiders to English, that they're not native speakers, and that the success of 
their novels is attributable to their "manufacture and promotion" for the "international market" (171).

My driving interest is not a critique of Casanova. What is significant, in my view, is how the dominant ideologies around nativity and Western address have been operative and continue to operate in works of literary criticism by Indian scholars themselves writing in English. For example, both Meenakshi Mukherjee's account of “twice-born fictions” and Tabish Khair's account of "Babu fictions" proceed from the assumption that English is a non-native, elite tongue in India, which does not and cannot relate to the Indian everyman. In the path breaking The Twice-Born Fiction, Mukherjee argued that vernacular Indian societal "values" (1971, 73), cultures, and social precepts could not be easily represented in Anglophone prose, given that the English language does not capture the "daily life of [Indian] people" (34). English therefore had to be indigenized, whether in dialogical "literal" translations of words spoken in the vernacular, or in the whole style of a novel. Following this argument, a certain deliberate and self-conscious Indianization became the mark of literary Indian English and was even retrospectively applied to the Indian Anglophone novel of the early $20^{\text {th }}$ century. Thus, critics could draw a line from the "tempo of Indian life" that "infuse[s]" Raja Rao's 1938 Kanthapura (vii), to the "rigmarole" tongues of G.V. Desani's All About H. Hatterr (published and revised many times between 1948 and 1972), to the "chutnefied" writing of Rushdie and heirs. The anodyne English prose of call center novels like Bhagat's is a perverse update on this tradition that shows us how Indian Anglophone literature has learned to suppress "Indian" difference in order to perform the difference of the New India.

There is a thoroughgoing ambivalence at the heart of the idea of globalization. Understood as process, it requires that the globalized subject in question - here, India - is 
retroactively understood to have been provincial, local, not-yet-of-the-world. And yet, the call center agent is an (the) iconic global Indian subject who has succeeded an Indian subject, the expatriate writer, who was always already, if otherwise, global. This is why the call center agent has gone, in the scholarly discourse, from being figured as a "cybercoolie" to a "cosmopolitan," and back again. It is a trajectory that echoes the ambivalent postcolonial literary discourse on the Indian Anglophone expatriate writer, who has similarly been charged with "Babu-ism," selfOrientalization, and capitulation to Western audiences and markets, even as s/he is also the subject of a new literary "cosmopolitics" (Ghosh 2004). In the call center as in literature, it is not always clear who is provincial and who is worldly, who is speaking for herself and who is speaking to the bottom line, whose difference is authenticating, and whose is merely marketable. The call center seems to represent a form of Anglophonism that is at once Indian and global, national and diasporic, but this is less a unique mediation of the language of capital, English, than it is the latest manifestation of a longstanding Anglophonic complex that undergirds India's legibility on the world stage and licenses its participation in the global capitalist order. In pursuing the question of the call center's emergence as the iconic subject of India's insertion into global capitalism, we do well to recall why, how, and on what terms we were drawn to its subjects in the first place.

\section{Notes}

[1] My thanks to the anonymous reviewer and special issue editors, Cheryl Naruse, Shashi Thandra, and Sunny Xiang, for very helpful feedback on an earlier version of this essay. I'm particularly grateful to Colleen Lye, who saw pieces of this while I was writing my doctoral dissertation and whose incisive words continue to inform my attempts at reformulation. 
[2] It is conventionally assumed that India's period of greatest economic growth postliberalization - its "dream run" from 2003-2008 — was led by the service sector, namely Information Technology, software services, and telecommunications. But some argue that the economic output of India's service sector has been rhetorically overstated, and that the growth in that sector was only ever a small part of a widespread "world boom" in services. If this is the case, then the story of New India as having been built through services, not manufacturing, through a relation of assistance and subordination, as opposed to the performance of creation and invention, may point to a more insidious discursive structure, one which we can situate in relation to earlier narratives of Indian arrested development and civilizational apprenticeship. The service sector also includes trade, hotels, restaurants, transport, storage, finance, insurance, real estate, and services generally classed as business, communal, social, and personal. See Nagaraj and Mukhopadhyay.

[3] There are two primary readings of virtual migration: one that emphasizes the agent's retention of nationality, and one that foregoes it. In A. Aneesh's account, virtual migration is not territorial or physical; thus, call center labor may be said to take place within the boundaries of the nation-state, and the call center agent ultimately retains her national identity (2006). Similarly, Reena Patel emphasizes that agents remain anchored in India by technologies like the mobile phone, which enables family and friends to stay in contact with the agent irrespective of her virtual itineraries (62). Contrasting studies dispute the virtual migrant's retention of nationality, arguing that "the agent is absent - no longer found in India because she is temporally removed. She has virtually migrated to America" (Rowe et al., 2013, 23). The call center agent's experience of moving between point $a$ and point $b$ in this account is "not merely imagined." What is at stake in this argument about retained or foregone nationality are the conditions under which one can argue that the call center agent is herself a "foreign-returned" subject who experiences "a diasporic sense of loss, longing, and nostalgia for an India [she] cultivate[s] from a sensibility of distance" (Rowe et al, 2013, 5) —whether, in other words, we are to do away with a key postcolonial concept like hybridity, or move, in our social scientific studies of global India, toward a "new politics" of it (Shome 2006).

[4] Select visual mediations of the call center include the film Outsourced (Shadowcatcher Entertainment, dir. John Jeffcoat, 2006), the television series Outsourced (NBC, 2010-2011), the film Call Center Girl (Star Cinema, dir. Don Cuaresmo, 2013), the play Disconnect (Anupama Chandrasekhar, American premieres, 2013), the art installations "Call Cutta" and "Call Cutta in a Box" (Rimini Protokall, world premiere, 2008), the theatrical production, "Alladeen" (The Builders Association, 1999-2007), and Annu Palakunnathu Matthew's mixed media photo animation and video series, "The Virtual Immigrant" (2017).

[5] In the past two decades, this image has been widely discussed as epitomizing the problem of Indian Anglophone literature's historic overdetermination by its reception in the West. When literary scholars critique the fetishization of diaspora in postcolonial studies, or the Anglophone novel's hegemony in the Indian literary sphere, it is often quite literally to this image that they are pointing. Of particular note is the deeply ironic caption the photo was given: "India's leading novelists." The photo was taken in London, and all but one of the writers had flown in from outside India, from Amsterdam, Vienna, Boston and New York, so the majority of "India's novelists" pictured were actually expatriates living outside of India. 
[6] A closer reading of Figure 2 illustrates the ambivalence of the discourse under discussion. Looking at the identical cubicles pictured, at the faceless subjects gazing into the blue-screened banality of the computer monitor, it is easy to see why some have argued that the call center is as exploitive as the sweatshop. By that same token, it is not apparent what each agent is looking at on his or her screen, and they themselves embody a variety of forms of physical comportment: slouching in desk chairs, walking around, leaning forward, conversing, heads cocked against headsets. It could be that what is depicted is an entrepreneurial greenhouse for a generation of aspiring global citizens, and that even the forms of climatic regulation on display here, to stay with the greenhouse metaphor, are in service of individual growth and economic mobility. Of the seventeen call center agents pictured, six, or roughly 35\%, appear to be women, which maybe means that the call center is a progressive outlet in which Indian women can seek opportunity and economic advancement. By that same token, inducting young women into the workforce is why some detractors view the call center as an existential threat to India's traditional life-worlds.

[7] This is not a unique story. Philadelphia-based filmmaker Sonali Gulati, director of the 2005 call center documentary Nalini by Day, Nancy by Night, was similarly inspired to return to India after receiving a call from a telemarketer who called himself "Harry Smith" but then, impossibly, "pronounced her name with effortless precision" (Gresham). Harry, real name Harvinder, was in fact a call center agent from Gulati's own home town. I first heard this story at the 2018 MLA in a conference presentation by Pooja Rangan.

[8] For Stuart Hall's diasporic subject of the Caribbean, there could be no return to a territorial homeland. For James Clifford and Paul Gilroy, "routes" were never guaranteed to secure "roots." In recent years, studies of diaspora have moved toward even greater emphasis on extraterritoriality: for example, Brian Axel's work on Khalistan, and Jasbir Puar's affect-oriented account of homelands "cohered through sensation, vibrations, echoes, speed, feedback loops, recursive folds and feelings" (171). Purnima Mankekar's India is citational, and can be traced through its "construction" as "an archive of affect" $(2015,4)$. Mrinalini Chakravorty's work on the stereotype in the global literary imaginary also emphasize extra-territorial mediations of India that offer "extravagant invocation[s] of reality in terms of difference," as opposed to ontological identity (220).

\section{Works Cited}

Agrawal, Prashant. "Why Narendra Modi will deliver his UN speech in Hindi," Quartz India, September 27, 2014, http://qz.com/272169/why-narendra-modi-will-deliver-his-unspeech-in-hindi. Accessed 18 April 2018.

Aneesh, A. Virtual Migration: The Programming of Globalization. Duke University Press, 2006.

--. Neutral Accent: How Language, Labor, and Life Become Global. Duke University Press, 2015. 
Anjaria, Ulka and Jonathan Shapiro Anjaria. "The Fractured Spaces of Entrepreneurialism in Post-Liberalization India." Enterprise Culture in Neoliberal India: Studies in Youth, Class, Work and Media, ed. Nandini Gooptu. Routledge, 2013.

Appiah, K. Anthony. In My Father's House: Africa in the Philosophy of Culture. Oxford University Press, 1992.

Axel, Brian Keith. "The diasporic imaginary.” Public Culture 14.2, 2002.

Basi, J.K. Tina. Women, Identity and India's Call Centre Industry. Routledge, 2009.

Bhabha, Homi. The Location of Culture. Routledge, 1990.

Bhagat, Chetan. One Night@the Call Center. Rupa Paperbacks, 2005.

--. What Young India Wants: Selected Non-Fiction. Rupa Publications, 2014.

Casanova, Pascale. The World Republic of Letters, trans. M.B. DeBevoise. Harvard University Press, 2004.

Chakrabarty, Dipesh. Provincializing Europe: Postcolonial Thought and Historical Difference. Princeton University Press, 2000.

Chakravorty, Mrinalini. In Stereotype: South Asia in the Global Literary Imagination. Columbia University Press, 2014.

Chand, Vineeta. "[v] at is going on? Local and global ideologies about Indian English." Language in Society 38.4, 393-419, 2009.

Chandra, Vikram. "The Cult of Authenticity." Boston Review 25, 2000.

Chow, Rey. The Protestant Ethnic and the Spirit of Capitalism. Columbia University Press, 2002.

--. Not Like a Native Speaker: On Languaging as a Postcolonial Experience. Columbia University Press, 2014.

Clifford, James. “Diasporas.” Cultural Anthropology 9.3, 302-338, 1994.

D'Costa, Anthony P. ed., A New India? Critical Reflections in the Long Twentieth Century. Anthem Press, 2010.

Deb, Siddhartha. The Beautiful and the Damned: A Portrait of the New India. Faber and Faber, 2011.

Desani. G.V. All About H. Hatterr. New York Review Books Classics. 2007 (1948, 1970). 
Fisher, Mark. Capitalist Realism: Is there no alternative? O Books, 2009.

Ghosh, Bishnupriya. When Borne Across: Literary Cosmpolitics in the Contemporary Indian Novel. Rutgers University Press, 2004.

Gikandi, Simon. "Between roots and routes: cosmopolitanism and the claims of locality," in Rerouting the Postcolonial: New directions for the new millennium, ed. Janet Wilson, Cristina Sandru, Sarah Lawson Welsh. Routledge, 2010.

Gilroy, Paul. The Black Atlantic: Modernity and Double Consciousness. Harvard University Press, 1993.

Giridharadas, Anand. India Calling: An Intimate Portrait of a Nation's Remaking. Times Books/Henry Holt and Co., 2011.

Gooptu, Nandini, ed. Enterprise Culture in Neoliberal India: Studies in Youth, Class, Work and Media. Routledge, 2013.

Gresham, Tom. "Film earns accolades for VCU professor," $V C U$ News, March 8, 2006, https://www.news.vcu.edu/article/film_earns_accolade_for_vcu_professor. Accessed 18 April 2018.

Gupta, Akhil and Purnima Mankekar, "Intimate Encounters: Affective Labor in Call Centers," positions 24. 1, 17-43, 2016.

Hall, Stuart. "Cultural Identity and Diaspora." Identity: Community, Culture, Difference, ed. Jonathan Rutherford. Lawrence and Wishart, 1990.

Harvey, David. The Condition of Postmodernity: An Enquiry into the Origins of Cultural Change. Wiley-Blackwell, 1989.

Jackson, Shannon. Social Works: Performing Arts, Supporting Publics. Routledge, 2011.

Jagannathan, R. "Behind Pankaj Mishra's rants: A pathology of Hindu-phobia and self-hate," Firstpost.com, October 26, 2014, https://www.firstpost.com/india/behind-pankaj-mishrasrants-a-pathology-of-hindu-phobia-and-self-hate-1772105.html. Accessed 18 April 2018.

Joshi, Priya. "Chetan Bhagat: Remaking the Novel in India," A History of the Indian Novel in English, ed. Ulka Anjaria. Cambridge University Press, 2015.

Krishnamurthy, Mathangi. "Furtive Tongues: Language Politics in the Indian Call Centre," Chutnefying English: The Phenomenon of Hinglish, ed. Rita Kothari and Rupert Snell. Penguin Books, 2011.

Kumar, Amitava. Away: The Indian Writer as an Expatriate. Routledge, 2004. 
Lavigilante, Natasha. “Globalization and Change in India: The Rise of an 'Indian Dream' in Miss New India: An Interview with Bharati Mukherjee," MELUS: Multi-Ethnic Literature of the U.S. 39.3, 178-194, 2014.

Mankekar, Purnima. "Becoming entrepreneurial subjects: Neoliberalism and media," The State in India After Liberalization: Interdisciplinary Perspectives, eds. Akhil Gupta and K. Sivaramakrishnan. Routledge, 2011.

--. Unsettling India: Affect, Temporality, Transnationality. Duke University Press, 2015.

McGuire, Meredith L. "“"How to Sit, How to Stand": Bodily Practice and the New Urban Middle Class," A Companion to the Anthropology of India, 115-136, 2011.

Menon, Jisha. "Calling Local/Talking Global: the cosmo-politics of the call-center industry," Women \& Performance: a journal of feminist theory 23.2, 162-177, 2013.

Merchant, Khozem. "India's Call Centres Drop the Fake Accents," The Financial Times. December 8, 2003.

Mirchandani, Kiran. Phone Clones: Authenticity Work in the Transnational Service Economy. Cornell University Press, 2012.

Mukherjee, Bharati. Miss New India. Houghton Mifflin Harcourt, 2011.

--. "Preface,” Darkness and Other Stories. Penguin Books, 1985.

Mukherjee, Meenakshi. The Twice Born Fiction; Themes and Techniques of the Indian Novel in English. Heinemann, 1971.

--. "The Anxiety of Indianness: Our Novels in English," Economic and Political Weekly 28.48, 2607-2611, November 27, 1993.

Mukhopadhyay, Sukumar. "Globalisation and Indian Services Sector," Economic and Political Weekly, Vol. 37, No. 40 (Oct. 5-11, 2002), pp. 4097-4098.

Nadeem, Shehzad. "Macaulay's (cyber) children: The cultural politics of outsourcing in India," Cultural Sociology 3.1, 2009.

--. Dead Ringers: How Outsourcing is Changing the Way Indians Understand Themselves. Princeton University Press, 2011.

Nagaraj, R. "Is Services Sector Output Overestimated? An Inquiry," Economic and Political Weekly, Vol. 44, No. 5 (Jan. 31 - Feb. 6, 2009), pp. 40-45.

Ong, Aihwa. Flexible Citizenship: The Cultural Logics of Transnationality. Duke University Press, 1999. 
Patel, Reena. Working the Night Shift: Women in India's Call Center Industry. Stanford University Press, 2010.

Puar, Jasbir. Terrorist Assemblages: Homonationalism in Queer Times. Duke University Press, 2007.

Ramesh, Randeep. “Author's mass-market success upsets Indian literati,” The Guardian. October 8, 2008, https://www.theguardian.com/world/2008/oct/09/india. Accessed 18 April 2018.

Rao, Raja. “Author's Foreword,” Kanthapura. Oxford University Press, 1947, 1938.

Rowe, Aime Carillo, Sheena Malhotra, and Kimberlee Perez. "The Rhythm of Ambition: Power Temporalities and the Production of the Call Center Agent in Documentary Film and Reality Television," Critical Rhetorics of Race, ed. Michael G. Lacy and Kent A. Ono. New York University Press, 2011.

--. Answer the Call: Virtual Migration in Indian Call Centers. University of Minnesota Press, 2013.

Roy, Arundhati. "Power Politics: The Reincarnation of Rumpelstiltskin," Outlook India, Nov. 27, 2000, https://www.outlookindia.com/magazine/story/power-politicsthe-reincarnationof-rumpelstiltskin/210449. Accessed 18 April 2018.

--. Capitalism: A Ghost Story. Haymarket Books, 2014.

Rushdie, Salman. Midnight's Children. Penguin Books, 1981.

--. The Satanic Verses. Random House, 1988.

Sanyal, Kalyan. Rethinking Capitalist Development: Primitive Accumulation, Governmentality, and Post-Colonial Capitalism. Routledge, 2007.

Sengupta, Somini. The End of Karma: Hope and Fury Among India's Young. W.W. Norton \& Company, 2016.

Sharma, Sarah. In the Meantime: Temporality and Cultural Politics. Duke University Press, 2014.

Shome, Raka. "Thinking through the diaspora Call centers, India, and a new politics of hybridity," International Journal of Cultural Studies 9.1, 105-124, 2006.

Sonntag, Selma K. "Linguistic globalization and the call center industry: Imperialism, hegemony or cosmopolitanism?" Language Policy 8, 5-25, Springer 2009. 
Spivak, Gayatri Chakravorty. "Can the Subaltern Speak?” Can the Subaltern Speak? Reflections on the History of an Idea, ed. Rosalind C. Morris. Columbia University Press, 2010.

Srinivasan, Ragini Tharoor. "The Rhetoric of Return: Diasporic Homecoming and the New Indian City," Room One Thousand 3, Global Urban Humanities Initiative: eScholarship, 2015.

--. "Unmoored: Passing, Slumming, and Return-Writing in New India," Postcolonial Urban Outcasts: City Margins in South Asian Literature, eds. M. Chakraborty and U. AlWazedi. Routledge, 2017.

--. "Introduction: South Asia from Postcolonial to World Anglophone," Interventions: International Journal of Postcolonial Studies, forthcoming, 2018.

Varughese, E. Dawson. Reading New India: Post-Millennial Indian Fiction in English. Bloomsbury Academic, 2013.

Vora, Kalindi. Life Support: Biocapital and the New History of Outsourced Labor. University of Minnesota Press, 2015.

Walkowitz, Rebecca. Cosmopolitan Style: Modernism Beyond the Nation. Columbia University Press, 2006.

--. Born Translated: The Contemporary Novel in the Age of World Literature. Columbia University Press, 2015. 